HD

9390

UC-NRLF

$\mathrm{G}_{3} \mathrm{C}$

\$B 39 264 


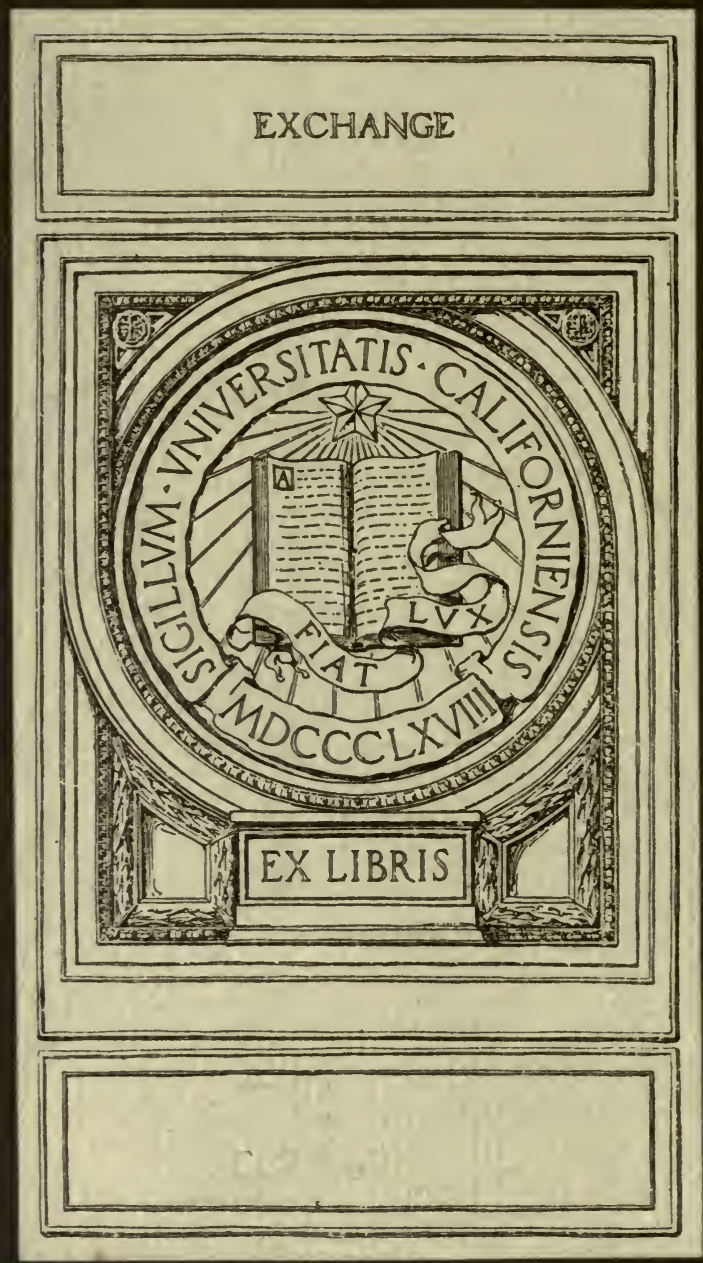




\section{DISTILLING IN GERMANY}

WITH PARTICUAR REFERENCE TO ITS

\section{AGRICULTURAL SIGNIFICANCE}

A Part of a Thesis Presented to the University of Michigan

BY CARL H. COOPER

For the Degree of Doctor of Philosophy.

No person visiting Germany, who has the opportunity to observe the industry and the agriculture of the country, car fail to be impressed with the large number of distilleries and breweries everywhere to be found. The preparation of alcoholic liquors is, to-day, one of the most important branches of German industry, and in many ways occupies a peculiar position in the industrial life of the Nation.

As the result of an interest in the subject awakened througin favorable opportunities for observation, a study of the alcohol industry was made by the writer, both distilling and brewing. being considered. It was attempted to trace the historic development, and to discover the present economic significance, industrially and socially, of this very important branch of business àctivity.

The present paper is a portion of the former one, considerably altered, and with much of the statistical material omitted, and seeks to trace the development and present condition of distilling, particular attention being given to its agricultural significance.

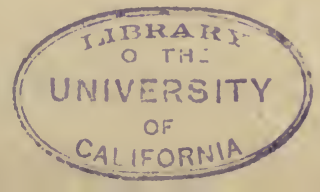


A. D., and as the German name "brannt-wein" would indicate. However the distillation of grain was known to Rhazes: as early as 860 A. D. ${ }^{1}$ In the eleventh century Afrikasas, a Spanish physician, mentions alcohol in his writings, and it was known to other chemists and physicians, but the methods of preparation were treated as a mystery. ${ }^{2}$

b. Introduction into Germany and Spread of Its Use.

In the thirteenth century, through the Arabians, it began to be used as a medicine, and quantities were introduced into Germany from Italy, at the beginning of the fourteenth century, as a remedy against the plague. Until the end of the fifteenth century it appears to have been used chiefly as a medicine or elixir of life, but during the following decades its use as a beverage became so common that the quantity produced from wine was not sufficient to supply the demand, and the practice of distilling wine lees and beer residues began. In a short time distilling became a sort of branch of brewing. ${ }^{3}$ Finally, the increasing use led to the direct production of alcohol from grain, which dates from $15900^{4}$ The evils resulting from the use of spirits, as well as the fear of famine, caused through the distillation of grain, induced many princes to issue mandates forbidding or controlling the production and use of acohol.

The landgrave of Hesse forbade the use of alcohol in 1524 . All distillation but that from wine and brewers' grains was forbidden in Electoral Saxony in 1595, and in Bavaria in 1553 and $1604 .^{5}$ Absolute prohibition of the use of spirits as a beverage was frequently enforced during the entire fourteenth century, but distilling also began to be recognized as a productive industry, needing rather to be controlled than to be suppressed.

The 'Thirty Years' War resulted in greatly increasing the consumption of spirits; camp life, the destruction of the

1. Hoefer, F., "Histoire de la Cemie." Paris, 1869 ; p. 341.

2. Stahlschmidt, pre. cit., p. 270.

3. Meitzen, Aug., "Der Boden u die landwirtschaftliche Verhaeltnisse des Pr. Staates. Berlin, 1862; vol. ii., p. 378.

4. Stahlschmidt, pre. cit., p. 270.

5. Wolf, "Der Branntweinsteuer," p. 44. 
vineyards, and the misery of the period contributing to this end. However, its use was chiefly confined to the cities, and it was not until after the Seven Years' War that alcohol became the drink of the poor peasants, among whom the habit spread with great rapidity. ${ }^{1}$

\section{c. Character of Early Distilling.}

In the beginning, production was chiefly carried on in cities. In Prussia, the Great Elector forbade distillation outside the cities, and not until the end of the serenteenth century was the privilege extended to the manors. ${ }^{2}$ This: monopoly was very important to the towns, as the distilleries, not being hampered at first by guild restrictions, and having. a ready sale for their prcciuct at good prices, grew rapidly. Dreyhaupt, in 1750, ca'led the business "Eine Alte Nahrung" of Halle, which had 35 distilleries in 1756 , and the saine was true of many other cities, particularly those situated in good grain growing districts. ${ }^{3}$ With the poor transportation facilities, grain was not easily and profitably disposed of; but when distilled into alcohol, rye became a much more portable, valuable commodity, and in addition the waste of the stili furnished an excellent food for animals. So swine iraising was carried on in connection with distilling, with very lucrative results. The gains soon showed themselves-still greaterin connection with cattle-feeding, so land-owners hastened to establish stills on their possessions, in order to profit through the maintenance of more cattle, which the by-products of the - distillery alone made possible.

With the growth of the industry, and a recognition of its agricultural importance, the earlier restrictions against the use of grain were removed, as the States now wished rather to foster than to hinder the development of what had become a weighty source of revenue. As early as the sixteenth century: taxes began to be levied on alcohol by German States, chiefly as local taxes on consumption. In Bavaria, Amberg imposed.

1. Baer, pre. cit., p. 223.

2. Wolf; p. 45.

3. Schwetschke, Gewerbliche Geschichte der Stadt Halle. Halle, 1883 ; pp. 211 and 216. 
a local tax on spirits in $15 \% 7$, while a tax on imports and exports was established, for all the provinces, in 1542. Such taxes were also raised in Brandenburg, in 1575; in Saxony, in 1595 ; and in various other States, and by the end of the following century alcohol taxes were generally an important part of the revenue system. ${ }^{1}$

II. From the Beginning of the Nineteenth Century to 18si. a. North German States.

1. Introduction.

A study of the statistics of the production of alcoholic liquors in the different states of Germany during the nineteenth century gives one a good idea of the agricultural and industrial changes that have taken place within this long period, and of the influence which the formation of the Customs Union, the improved transportation facilities, the introduction of steam power and machinery, industrial freedom, the growth of eapitalism, and the creation of the German Empire, have had on agriculture and industry in general. In Germany, at the beginning of the century, trade and production were still hampered by almost mediaeval restrictions. The craft guilds still existed in many places and with their regulations (Bann and Zwang Rechten) exerted an injurious effect on industrial derelopment. Still more harmful, however, was the division of Germany into a large number of independent tax and tariff districts, which made extensive trade almost impossible. Agriculture was still carried on in a very primitive way, little if any improvement having been made for centuries. Mecanical aids, with the exception of those borrowed from the ancients, were unknown. The method of cultivation was the so-called three-field system, in which grain is raised upon the land for two years, while during the third year the field lies fallow, i. e., not sown, but plowed and cultivated in order to cleanse it from the weeds, which cannot be destroyed when land is sown to grain. Under this system of agriculture, which was universal, one-third of the farming land of Germany lay idle and a great economic loss resulted.

1. Wolf, "Die Branntweinsteuer," p. 82. 
The beginning of the century was marked by a great increase in the consumption of aleoholic liquors of all kinds, which was largely oceasioned by the economic difficulties and horrors of the Napoleonic period, and the spread of the custom through the returning armies. Distilleries and production inereased very rapidly, particularly in the country, where the raw materials were close at hand. This period of growth was also one of reform. The abolition of mediaeval conditions, the creation of a Customs Union and the introduction of uniform taxation have been most potent in aiding the industrial development of Germany, and as the first steps toward reform were usually taken by Prussia we will first consider that kingdom.

\section{Prussia.}

Prussia, containing some of the most fertile districts of Germany, well suited to the raising of rye and other grainz, possessed a considerable distilling industry at the beginning of the century. The establishments were chiefly found in the important agricultural provinces of Silesia, Saxony, Brandenburg, East Prussia and Posen. There were a considerable number of distilleries of fair size running the year round and found in or near the cities. Then, in the cities, were the little stills connected with a bar, over which the product was dispensed. In the country, the majority of the plants werc run only during the fall and winter months or as long as the grain lasted and in connection with agriculture. Those of the district along the Rhine were operated only a few days or weeks, and produced brandy from the spoiled fruit, wine lees, etc. Finally, numerous brewers still continued to produce whisky from the brewers' grains, or that part of the malted grain remaining after the wort has been extraeted. The growth of the industry was greatly hampered, however, by the various taxes to which it was subjected.

Prussia still retained at the beginning of the century an antiquated and complicated excise system, of which many features had been borrowed from the French. Alcohol was placed under different taxes in all the various provinces and cities. Distinctions were made between eountry and city dis- 
tillers, and boundry taxes were raised by the several divisions of the monarchy. In all there were 67 different tariffs existing. ${ }^{1}$ Under the Stein-Hardenburg ministry steps were taken to free the industry from some of these claims. First, the ancient monopoly rights of production and sale (Branntweinzwang), held by guilds and individuals, were largely annulled by the edict of October 28, 1810. Then the edicts of October 27th and November 20th of the same year taxed all distilleries, city and country, alike. ${ }^{2}$ The form of the levy was the still tax, controlled through a tax on materials, viz., a tax according to the capacity of the worm. This position of equality with the city distilleries, the heavier burden, and the novelty of indirect taxation, resulted in such complaints from the country distillers that the raising of the tax was soon suspended, except as one on materials. Another attempt at a still tax was made by the edict of September \%, 1811, which retained the tax in its earlier form and height for the cities, but lowered it seventy-five per cent. for the country. The addition of territory through the wars of 1813-15 had introduced new complications into the tax system, and in 1819 (February 8 th) the still tax was extended over all parts of Prussia. ${ }^{3}$

After 1811 the complaints of the farmers over the new form of taxation largely ceased, as the industry had gone to work to produce as much alcohol as possible in a short time; or in the twenty-four hours taken by the law as the standard distilling period, to produce more alcohol than the law assumed, thus saving tax. During the second decade of the century distilling developed with great rapidity. This was largely the result of the low prices for agricultural products which followed the Napoleonic wars. Alcohol remained high, in price and distillation was considered the best means of utilizing the grain. So large numbers of land-owners erected stills. There were in Prussia in 1812, 19,203 such plants; in 1816, 24,092 ; and in $1820,35,364 .{ }^{4}$ p. 557 .

1. Conrad's "Handwoerterbuch der Staatswissenschaften;" 1st ed., vol. ii.

2. Wolf's Branntweinsteuer, p. 49.

3 , Wolf, pre. cit., p. 53.

4. Meitzen, "Boden u. landwirtschaftliche Verhaeltnisse, Etc.;" vol. ii.,p. 392. 
The problem which the still tax had set before the distillers soon bore fruit in great technical advanee. Improved stilis were invented by Pistorius and Dorn, ${ }^{1}$ which permitted direct distillation from the mash, and shortened the time very materially. But these advantages were chiefly for the larger city establishments, which could profit through the best apparatus and the most economic conduet of the business. On the other hand, country distilling was a business secondary to and dependent on agriculture. The extent and time of distilling was largely controlled by the amount of land cultivated, the number of cattle, the harrest, the fodder, ete. In addition, the farmer could not give the attention to distilling necessary for its most economic conduct, nor could he utilize fully the improved methods. Consequently, the burden of the tax rested more heavily on the eountry than on the industrial distillers, and the former began to eomplain very loudly of the unjust taxation. It was recognized that if agriculture was to retain the benefit derived from distilling, a reform must be brought about which would make the farmers stronger in eompetition and burden all equally. So in 1820 (December 1st), after eareful consideration, the still tax was abandoned and a tax on the capacity of tine masi tub (Maischraumstener) introdueed as an experiment and definitely adopted January 20, 1822, after experience had shown that it was an improvement over the other system. ${ }^{2}$

Of all forms of taxation that upon the eapacity of the mash tub is the best for building up the industry, technically and mechanically. It sets the problem before the distillers of producing the most alcohol possible from the smallest volume of mash, in order to evade part of the tax. 'To aceomplish this, more alcohol-producing materials to the same amount of water must be mashed in the same size tub than before, or thicker mashing must be resorted to. But in thick mashing the fermentation was not complete and a loss of materials re-

1. S. Meyer, Die Internationale Spiritus Production; art. i., p. 145. Vierteljahrsschrift fuer Volkswirtschaft, 1883.

2. Wolf pre. cit. p. 55 . At the rate of 52 marks a hundred hectoliters of mash tub, 2 per cent. of pure alcohol being taken as standard. 
sulted. In addition, the mashes had been cooked over an open fire up to this time, which endangered burning when they were too thick. But these difficulties were solved by the development of stronger ferments, which fully fermented the starch in thick mashes, and by the introduction of steam cooking apparatus. Through these improvements it was soon possible to mash as thickly as in the ratio of one part of dry substance to six or seven of water, while the ratio assumed by the law was one to eight. In other words, from every one hundred quarts of mash not the legal four but from six to eight quarts of alcohol were produced. ${ }^{1}$ But the small, particularly the agricultural distilleries, could not make such rapid advances as the industrial, and many of the improved appliances were too expensive as well as not economic in a distillery of small capacity run only a few months of the year. In addition, the revenue officials recognized that the improved technic had réally lowered the tax; so through the Cabinet order of January 10,1824 , an attempt was made to aid the farmers and also to raise the tax, which was fixed at 62 marks a hectoliter, or the yield taken as 2.4 per cent. of pure alcohol. The farmers using only grain or potatoes were taxed one-eighth less. $^{2}$

In spite of the technical and mechanical disadvantages under which the country distillers worked, the natural advantage coming from their connection with the soil were sufficient to impart great elasticity and competitive strength to them. As long as distilling paid for itself production could be continued, for the advantage of the fodder and the manure remained. The small city distillers, on the other hand, possessed no such advantage and when the large firms lowered the price of alcohol they were in most cases forced to discontinue.

A great assistance was given to the country distillers about this time by an agricultural revolution, accomplished largely through the efforts of Albrecht Thaer, ${ }^{3}$ the great agricultural p. 33.

2. Heckel, in Hwb. der Staatswissenchaften, 2 ed., vol. ii, p. 1063.

3. For an account of 'Thaer's life and services, see Meitzen, pre cit. vol. ii, p. 14 . 
reformer of Germany. It was chiefly through his activities that the antiquated three-field system of cultivation was given up and modern methods introduced in its stead. As we have seen, the fallows of the three-field system had the purpose of allowing the destruction of the weeds, which could not be accomplished with a grain crop. Thaer advocated the cultiva. tion of root crops, such as potatoes, turnips, beets, etc., on the fallows that have the advantage of being planted some distance apart, so allowing the cleansing of the soil, and at the same time yielding a valuable crop. Thus one-third of the land is saved to culture, and the value of the soil is much increased. Of these crops the potato proved of incalculable worth to the farmers of Germany, and particularly to those engaged in distilling; therefore, we will consider its introdustion and cultivation somewhat in detail.

Though the knowledge of the potato in Germany extends back to the sixteenth century, it having been grown in Frankfurt am Main in 1588 as a botanical curiosity, its culture, to any extent, did not begin until the middle of the eighteenth century, when its value as an article of food began to be appreciated during the years of famine and crop failure after the Seven Years' War. Frederick the Great did much to introduce it in his domain, and spread its culture in Pommerania and Silesia by force. However, it was not until the adoption of Thaer's ideas that the potato was taken from the garden and made a real agricultural plant. ${ }^{1}$ It prospers best on thin sandy soil, warm and dry, and Northern Germany is particularly well suited to its culture. In fact, whole districts that were formerly barren wastes have been reclaimed through the potato. The amount of sandy soil and ground classified as sand in the eight old Prussian provinces, particularly in the six eastern ones, is surprising. Of the entire surface of the kingdom the average amount of sandy loam and loamy sand is 27.4 per cent., and of sand 24.3. The average for the six eastern provinces is $3 \% .9$ and 33.0 respectively. The per cent. of sandy loam and loamy sand runs as high as 48.0 in Posen,

1. Meyer's Conv. Lexicon, 4 ed.. art. Kartoffel, p. 573. 
while that of sand is 42.5 in Brandenburg. ${ }^{1}$ But the potato is a bulky product and its value will not permit transportation to a distant market. It cannot be kept more than nine or ten months, and is easily spoiled through frost, rot, etc. Consequently, in order to profit most through its culture, where this is carried on extensively, it must be manufactured into a product which ean be easily stored and transported. This product may be either alcohol or stareh.

The potato can be mashed much thieker than grain or beets, and consequently yields more alcohol from the same sized mash tub. It also produces a much larger crop to the acre than grain, while the value of grain and potato spirits does not differ greatly. In 1829 , a Prussian statistician made the following eomparison: ${ }^{2}$

"One Morgen of land produces 6 sheffels of rye and 1 Morgen of land produces at least 80 sheffels of potatoes; but 6 sheffels of rye yield 72 quarts of 80 per cent. alcohol, while 80 sheffels of potatoes yield 400 quarts of 80 per eent. alcohol."

These advantages were soon recognized by the distillers, and from the moment that technical improvements allowed the removal of the unpleasant and injurious fusel-oil, ${ }^{3}$ which is present in raw potato aleohol in large quantities, potatoes were everywhere introduced into the distilleries, particularly among the farmers. In addition, from 1827 on, the price of grain rose, and the land-owners who wished to sell their grain at good prices, but still did not wish to loose the agrieultural advantage of distilling, went more and more orer to the safer and more profitable potato. ${ }^{4}$

The general condition of distilling in Prussia about 1830 was one of prosperity, and C.W. Ferber, a writer of the period, destribes it as follows:

"Whether one observes the raw material, which the land exculsively supplies, the increased value of the material from its

1. From Jahrbuch fuer die amtliche Statistik des preuss. Staates, vol. iii, 1869 , p. 92.

2. C. W. Ferber, Beitraege zur Kentniss der Gewerbl u. Komuerz. Zustandes der preuss. Monarchie. Berlin, 1829, p. 174.

3. Found also in grain alcohol, but in smaller quantities. (Amyloxydhydrat $\mathrm{C}^{12} \mathrm{H}^{11} \mathrm{O}+\mathrm{HO} \mathrm{O}$.)

4. Meitzen, pre. cit., vol. ii, p. 393. 
distillation, the growth in trade through this branch of manufacture, or whether one considers the endless advantages to agriculture and cattle raising which come from distilling, and the high intelligence with which this branch of Prussian business activity is conducted, everywhere the Prussian patriot has only reasons for great satisfaction and for certainty of the great national benefits derived from the excellently conducted distilleries, which are as well an important source of revenue for the public treasury."1

From 1831 to the present time statistical material is available from which we can gain a fairly good idea of the condstions prevailing in the distilling industry in Northern Germany. In the year mentioned there were in the eight old provinces of Prussia 22,969 distilleries, of which 13,806 were in operation during the year. 9,399 or 68 per cent. of these were agricultural, the remainder industrial. The largest number, 6,535, were found in the Rhine province, the distric of the fruit stills, while the largest number operated, 4,811, were in Silesia, where potato culture had become very common. The smallest numbers were found in Posen, 382, and Saxony, 1,019. By $188 \%$ the entire number of distilleries in the eight old provinces had diminished to $7,06 \pm ; 5,808$ being in operation, of which 1,000 and 4,796 were in the city and the country respectively, or 82 per cent. were agricultural. These facts indicate the concentration of production in large industrial establishments, and also the tendency of the distillers to withdraw to the country, where their plants are more profitable. In Posen, for instance, the city distilleries diminished in number during this period from 235 to 6 , while those in the country increased from 338 to 444 . The tendency to retire from the cities was much stronger among the pofato than among the grain distilleries, the number of the latter having decreased from 2,280 to 756 , or two-thirds, while the former decreased from 2,002 to 194 , or nearly 90 per cent., between 1831 and $1865 .{ }^{2}$ This is explained by the fact that

1. C. W. Ferber, pre. cit., p. 169 .

2. From Jahrb. fuer amtliche Statistik des preuss. Staates iv. Jhg. 1876, p. 310, Monatshefte zur Statistik des deut. Reiches 1880 and 1886, and Meitzen pre cit., vol ii, statistical part. 
raw grain spirits is much purer than that made from potatoes, and the direct retail of grain alcohol for drinking purposes is often carried on by distillers, the profits of which enable many small grain distillers to maintain an existence, while raw potato spirits is unfit for consumption without refining. So, with increased competition and higher taxes, the small potato distillers were forced to the ground, and only the larger ones have been able to maintain themselves.

The amount of potatoes used in the entire monarchy increased very greatly, being four times as much in $188 \%$ as in 1831 , or $6,607,582$ and $24,530,451$ double centners respectively. During the same period the increase in the quantity of grain was very much less, or from 2,170,522 to $3,108,701$ d. c. ${ }^{1}$

From the character of the tax on alcohol, the statistics of the amount of spirits produced in Prussia during the period under consideration must remain mere estimates, and are at best very uncertain, as they depend upon the quantity taken as the average amount of spirits produced from a certain volume of mash. This, we know, varied greatly with the thickness of the mash, and the distilling apparatus, and was alway: uncertain. Dieterici ${ }^{2}$ estimated the products in the eight old Prussian provinces at 171 mil. liters of 50 per cent. spirits for 1831, and at 224.5 mil. liters for 1839. In 1842, a low, careful estimate was $228 \mathrm{mil}$. liters, or a decrease from former years as a result of the potato rot. Then, too, the powerful temperance movement of the period had reacted on production, so we find the estimates decreasing, that for 1845 being 201 mil. liters. In 1838, the tax was raised from 62 to 72 marks for 100 hectoliters, and the assumed yield of alcohol from a quart of mash raised from 2 to 2.5 per cent., which for a short time lowered the product. In 1847 , distilling was partially forbidden to lower the price of potatoes. Unfavorable crops and high prices for materials continued to lessen the amount of alcohol produced, though favored by im-

1. From Jahrb. fuer Amtliche Statistik. etc., 1876 and Monatshefte, 1887.

2. C. F. W. Dieterici, Statist. Uebersicht der Wichtigsten Gegenstaende des Verkehrs u. Verbrauches im. preuss. Staat 1839 , p. $223 ; 1842$, p. $332 ; 1845$, p. 365. 
proved facilities, the tax was becoming smaller year by year, as the State's revenue indicates: 7,02t million thalers in 1839, and 5,494 in $1854 .{ }^{1}$ An attempt to remedy this condition was made in 1854 by raising the per cent. from 3.3 to 5 and the tax from 72 to 131 marks. The heavier tax had the immediate effect of increasing the revenue, but it also diminished the production. Large numbers of the smaller stills particularly were forced to cease operations, the number in Tax-Union active in 1854 being 7493 , and in $1856,673 \overline{5}^{2}$ Many of these had existed for years on the difference between the real and the nominal tax. The limit of thick mashing, etc., had been reached for them, and there was nothing left but to close, or to increase in size and so lower costs. Consequently, along with the disappearance of many, we also find the establishment of numerous large, well equipped plants and an increase in production. From 1872 to $1880-81$ there are estimates of the product in the official year books. The gross receipts from the tax are taken as a basis, and 26 marks 20 pfennigs as equivalent to a hectoliter of pure alcohol. This method, which can only be approximately correct and probably gives much less than the real amount, shows a production of 149 mil. liters of pure spirits for $18 \% 2$, with a constant increase for the years following. For the years after 1880 the estimates are our own: 1874, 178 mil. liters; 1876, 173; 1878,$181 ; 1880-81,192 ; 1882-83,200 ; 1884-85,211 ; 1886-$ $8 \%, 201$.

\section{Other North German States.}

\section{(a.) Introduction.}

In describing the alcohol industry of the other North German States it is not necessary to go into detail, as the conditions prevailing were, for the most part, very similar to those in the adjacent Prussian provinces. Of these independent States all save Saxony, Thuringia, Mecklenburg and Oldenburg have been absorbed by Prussia, though during a considerable part of the century they retained their independence and continued their separate tariff and revenue systems, much

1. Von Heckel in Conrad's Handwoerterbuch, 2d ed., vol. ii, p. 1063.

2. Zeitschrift des preuss. Statist. Bureaus. 1869, p. 117. 
to the injury of the best interests of Germany. The organization of the Customs-Union gave Prussia an opportunity to extend her system of taxation into some of the neighboring States. On March 30, 1833, an agreement was made with Saxony, and on May 10th with the Thuringian States, which resulted in a uniform system of taxation of alcohol. . Up to 1866 the Alcohol-Tax-Union (Brennsteuerverein) consisted of these three States alone: Prussia, Saxony and Thuringia. On January 1, 1866, Brunswick joined. In 186\%, Oldenburg took the same step, and Wiesbaden, Cassel, Hanover and Schleswig-Holstein were incorporated through annexation to Prussia. In 1868, the former Electorate of Hesse, the grand duchies of Mecklenburg-Schwerin and-Strelitz, the duchy of Launeburg, Lubeck, and parts of Hamburg, joined. In 1869, the grand duchy of Hesse; in 18\%2, the Hohenzollern Lands, and in 18\%4, Alsace-Lorraine completed the Union. With the formation of the North-German Bund, and later of the Empire, the product of the tax was made common, and only Bavaria, Baden and Wurtemberg retained independent systems of taxation. In 188\%, they also joined the Union and the taxation of spirits became imperial in character.

(b.) Saxony, 'Thuringia and the Remaining States.

Taking Prussia as typical of North Germany, a very brief mention of the conditions prevailing in the other States will suffice. The kingdom of Saxony, as the largest and most important, will be considered first.

Though a considerable portion of Saxony is mountainous and ill-suited to agriculture, still the northern and eastern parts, near Leipsic, are very fertile and highly cultivated. Here the grain and the potatoes are produced that maintain numerous country stills, together with some very large establishments in Dresden, Leipsic and other cities.

Up to 1833, through the influence of the old excise system, distilling remained in a very primitive, undeveloped condition, as compared with Prussia, but the introduction of the new tax on December 4, 1833, had a most beneficial effect, and in a short time in the place of the ill-equipped distilleries 
a number of modern establishments were erected. ${ }^{1}$ In 1833 , there were $4,65 \%$ so-called stills; in $1836,4,40 \%$, but only 1,684 operated. ${ }^{2}$ This decrease in numbers brought with it no injury but rather advantage to the industry in the more economic use of the materials distilled. Those operated were quite largely agricultural, $6 \% \%$ of the 1,684 , and $7 \%$ per cent. of all the materials used were potatoes. The number of plants diminished strikingly between 1836 and 1886-8\%, from $4,40 \%$ to 663 , but to a greater extent in the cities than in the country, the per cents. being 87 and 51 respectively.

Thuringia is rough and mountainous in all parts and though there are many fertile valleys, agriculture is carried on in a small way only, very few large farms being found. Consequently, distilling, agricultural or industrial, never became of great importance and has been in a condition of decline since the development in the other German States has increased competition. In 1840 there were operated 69 city and 356 country stills; in $1886-8 \%, 6$ and 51 respectively.

In the other States added to the alcohol-tax district grain distilling is of great importance and was early developed, Western Germany, particularly Hanover, Schlewig-Holstein and Hesse-Nassau, being well suited to the raising of grain. Potato culture is carried on extensively, however, and considerable quantities of potato alcohol are distilled in country stills in Mecklenburg, Schleswig-Holstein and Hesse. Mecklenburg; bordering on the Baltic Sea, and with very sandy soil naturally went over to the extensive culture of the potato. In Brunswick the conditions are very similar to those in the adjacent province of Saxony, and potatoes as well as sugar beets were early introduced, resulting in numerous molasses and potato stills. Hesse, Hesse-Nassau and Alsace-Lorraine on the Rhine, the center of German wine culture, contain numerous small fruit and brandy stills.

In $18 \% 2$ the active distilleries classified as grain, potato and fruit numbered as follows: ${ }^{3}$ Schleswig-Holstein, 70, 21;

1 E. Engel "Die Brauntweinbrennerei in inrer Bezıehung zur Landwirtschaft, ete.," p. 430.

2. Zeitschrift des koenjgl. Sachs. Statist. Bureaus.

3 From Statistik des deut. Reiches, 1874, vol. i, p. 75. Amounts for AlsaceLorraine for ' 73 . 
Hanover, 40\%, 43, 3; Hesse-Nassau, 203, 159, 8\% ; Hesse, 1, 215, 198; Mecklenburg, 26, 37 ; Brunswick, 19, 35, 2 ; Oldenburg, 42, 1; Alsace-Lorraine, 13, 109, 12,542.

b. South German States.

1. Bavaria.

We will next consider the history and the development of the industry in South Germany, taking Bavaria as the type for this section of the Empire and mentioning very briefly the other States.

On account of the continual prohibition of the use of grain for distilling purposes, the production of spirits remained for centuries almost entirely limited to that from fruit, wine and brewery residues. ${ }^{1}$ In fact distilling was very little more than a branch of brewing. Under these circumstances the quantity produced could not become very large and was chiefly used for medicinal purposes. ${ }^{2}$ These conditions remained very little altered until the grain famine of 1816-18 caused the extensive introduction of the potato into Bavarian agriculture and furnished a new material for the stills. The situa. tion was largely the same in the territories annexed to old Bavaria at the beginning of the century to form the modern kingdom, except that distilling from grain was quite important in some of the new districts. ${ }^{3}$

The system of taxing spirits reflects the conditions prevailing in production. Up to 1806 a tax on the finished product. was levied, but it was abolished and from 1806 to 1880 brewing and distilling were taxed in a similar manner, i. e., on the amount of malt used, the so-called "Malzaufschlag."4 The very fact that the levy upon beer and spirits was according to the same system indicates the close connection between the two. Bavaria was the great "Bierland" of Germany and the tax on beer was one of the chief sources of revenue, while that on spirits was of little importance, producing only about 20,000 florins annually, of which the half was from so-called

1. Wolf, “-Branntweinsteuer; p. 83.

2. Production at beginning of century only about 12,800 hec.-E. Meyer, V.j. s. fuer Volkswirtschaft, 1883 ; part 3, p. 147.

3. Ibid., 147.

4. Ibid.; p. 147. 
beer spirits, or that made from brewers' grains. The new law was drafted with reference to the best interests of the brewing industry and the government, while the tax on alcohol was included as a sort of side issue. Of course the law rested only on the spirits produced from malt. In 1808 (January 26), the taxes existing in different parts of the kingdom on fruit, wine and potato spirits were abolished and a uniform still tax introduced for them. Under the two laws the taxation was very unequal. Alcohol made from brewers' grains was really free, as the malt had already been taxed, while that from fruit, wine, etc., paid a relatively' high amount. These conditions caused numerous complaints, particularly from the farmers, and on February 11, 1811, the still tax was abolished. ${ }^{1}$ This made the tax on liquors exceedingly low in Bavaria, as only the small amount of malt used to develop the mash was assessed at all. As a consequence we find the industry developing very rapidly, particularly among the farmers using potatoes.

Bavaria is one of the garden spots of Germany and in the fertile river valleys and on the warm southern hills the crops are raised that built up long ago the sturdy prosperous peasantry for which the country is known. These men were not slow to discover the advantages of the potato, and soon the fields that produced the celebrated Bavarian brewing barley were frequently planted to the tuber, particularly after the crop failures of 1816-17, which, as we have seen, gave increased impetus to its cultivation. The necessity of utilizing the crop and the favorable condition of taxation rapidly increasec? the agricultural stills, and soon placed Bavaria in a position to export considerable quantities of liquor.

These favorable conditions of production and of export continued even after the union with the Zoll-Verein, until in 1841, the system of "Uebergaugsversteurung" was adopted viz., imported goods were assessed on the boundry the amount of the domestic tax, while the tax paid was refunded on goods exported. ${ }^{2}$ Bavaria levied a boundry tax on imported spirits,

1. Wolf, Branntweinsteuer, pp. 84-8j, and E. Meyer, pre. cit., p. 150.

2. Wolf, pre. cit., p. 86 . 
but there could be no payment of drawbacks on exports, as it was impossible to ascertain the amount of malt used in the production of the liquor. As a consequence Bavaria was forced to give up her export, the industry suffered much under foreign competition and imports soon became very large. For the years 1848 to 1852 the yearly excess of imports over exports averaged 3,322 hectoliters. For the years $18 \% 4$ to '78 the excess had increased to 139,426 hectoliters. ${ }^{1}$

In Bavaria, Right of the Rhine, there were in 1859, 5,524 establishments for the manufacture of spirits, producing 68,274 hectoliters of pure alcohol. ${ }^{2}$ The statistics do not separate the agricultural from other distilleries, but joins those carried on in connection with farming and brewing. However, we can see that the agricultural stills must have been numerous, as the entire number of breweries in 1865 was only 5,171 , while the distilleries numbered 5,47\%. ${ }^{3}$ Many of them, however, were very small and run in connection with wine presses for a few days only. The number operated increases greatly in good wine years, as in 1879 when there were 11,423 or double the average number, while the yield 93,245 hec. was very little larger than that of the preceding years. Materials were not distinguished before 1880 .

In Bavaria, Left of the Rhine, no tax was-levied on spirits. The distilleries, which numbered 1,450 in 1860 , were mostly small fruit stills, the Palatinate being a famous wine country.

On February 25, 1880, the antiquated system of taxation was finally abandoned and a new law based on that in use 11 the North German Association adopted. The industry was taxed independently of brewing and the different needs of the different classes of distillers considered, as well as the most productive and just method of levying the tax. The standard rate was the same as in North Germany, 1.31 marks a hectoliter of capacity of the mash-tub. The small agricultural stills were also farored by a lower assessment, five-sixtlis the nor-

1. Meycr, "Die Internationale Spiritus Production," in Vierteljahrschrift fuer Volkswirtschaft, 1883; pp. 152-153.

2. From Zeitschrift des Koenigl. Bay., Statist. Bureaus, 1860-72.

3. E. Struve, "Bayerisches Brau-Gewerbe." Leipsic. 1893; p. 95. 
mal rate. The influence of the new law upon the industry was good.

We are now in a position to determine the number and the importance of the country stills, as the law necessitated their segregation. The vast majority were found in the country, 5,990 out of $6,49 \%$ in 1885 . Of these the greater number ${ }^{1}$ were small, producing not more than 5 hectoliters of 50 per cent. alcohol yearly, and using chiefly fruit and wine. However, 1,256 used potatoes during this year; and the annual consumption of the tuber was from 1 to 1.5 million hectoliters, being $1,141,411$ in 1885 . A considerable market for grain was also furnished by the stills, 734 using 313,750 hectoliters in the same year, as well as 126,754 hectoliters of brewers: grains. The product varied from 222,034 hl. in 1881 to 261,002 in 1885.

In 188\%, Bavaria, with the other South German States, came under the jurisdiction of the imperial tax on spirits.

2. Wurtemburg.

Distilling in Wurtemburg is almost exclusively carried on in the simplest way possible and has never become of great industrial importance. The country has a very dense population and the agricultural lands are divided into exceedingly small parcels, cultivated chiefly by their peasant proprietors. According to the census of 1895 , there were 306,643 farms in the kingdom and 142,910 persons owned land amounting ts $1,378,263$ hectares of the entire surface of $1,498,949$ hectares, a hectare being 2.5 acres. Stills are operated by these small farmers for a short season only, chiefly to gain a little fodder for the cattle or to utilize waste. The country is famous for its numerous vineyards, and the owners distill brandy from the residues of the presses, while in the Black-Forest the poor inhabitants distill the heidelberries which abound. Most of this distilling lasts but a few days or weeks, and the product is either consumed at home or sold to gain a little ready money. These conditions have apparently prevailed since distilling was introduced. Little room was given for the growth of a real industry and one has never developed.

1. 4,502 in 1887. 
The statisties of production during the early part of the century are scanty and until 1885 unsatisfactory, because of the numerous changes and curious methods of taxation, seven. different laws having been in operation between 1807 and 1885. The changes were chiefly brought about by the difficulty in finding any system of taxation not injurious to the small agricultural stills that would be productive of revenue. Before 1842 no statistics of the number of distilleries exist. In 1842 there were 9,139 stills; in $1850,9,799$, and the estimated product 38,986 hectoliters. ${ }^{1}$ From 1859 to 1864 the average number operated was 10,733 and product 47,983 hectoliters. ${ }^{2}$ From 1865 to 1885 a system of malt taxation, patterned after the Bavarian, was used and no statistics were collected. In 1885 the taxation was harmonized with that of North Germany, and in $188 \%$ independent taxation was given up. In 1886-8\%, 7,885 stills were operated of which 1,560 used potatoes, 2,282 grain, 1 molasses, 7 beets, 3,163 fruit, 848 brewers' grains, and 44 other materials; 7,067 of them produced only up to 5 hectoliters of alcohol and 55 exceeded 50 hectoliters. $^{3}$

\section{Baden.}

Situated along the upper Rhine and containing a portion of the Rhine valley, Baden is a very fertile agricultural country and contains, besides very numerous small farms, great numbers of vineyards. It is the land of small distilleries, largely in the hands of the wine-growers. At the beginning of the century there were about 20,000 of them in operation during the wine season, but real industrial distilling scarcely existed. These conditions continued until after 183\%, when distilling began to develop in the grand-duchy and little by little larger plants with improved apparatus were established. This growth was largely due to the introduction of a tax according

- to the still capacity. ${ }^{4}$ As in Prussia, this brought improved methods to enable escape from taxation, and so steady development. The system of taxation remained unchanged until

1. Wuertemberg Jahrbuch, $1851 ;$ p. 202.

2. Ibid, $1865 ;$ p. 82.

3. Monatshefte zur Statistik, Etc., for 1887.

4. Wolf, Branntweinsteuer, p. 112. 
Baden passed under the jurisdiction of the imperial law in $188 \%$, but the rate was several times increased after $183 \%$ The number of distilleries at different times numbered as follows: $1829,20,000 ; 1849,22,111 ; 1862,22,882 ; 1870$, 26,$505 ; 1876,26,596 ; 1880,28,498 ; 1886,28,260 .^{1}$ 'These numbers do not indicate those in operation, which were probably a great many less. The product is also very uncertain. The official estimates for several years were as follows: 1872 , 11,805 hectoliters; $18 \% 4,10,065 ; 18 \% 6,63,526 ; 1878,3 \%, 040$. Wolf estimated the amounts as follows: $1874,35,000 \mathrm{hl}$; $1875,80,000 ; 1876,83,000 ; 187 \%, 55,025$. The great variations were caused by the fruit and wine crops. The product did not cover the demand and great amounts were imported, usually double the estimated production.

III. The Present Industry.

a. Introduction.

We have now brought our description of distilling in the different parts of Germany down to $188 \%$, in which year the imperial tax system was extended orer all the States. From this time on we are able to consider the industry as a whole with similar taxation and similar statistical data, and from 1887 we may date the present industry. In the following pages we will attempt to describe some features of distilling as it was in 1899, bringing out the changes that have taken place within recent years and also the tendencies of the industry, wherever this seems feasible.

$b$. Number of Distilleries.

On the 30th of September, 1899, there were in all parts of the Empire 88,582 distilleries of various kinds, and during the fiscal year 60,926 of them were in operation for a part or the whole of the time. The number has diminished slightly since $188 \%$, when it was 90,899 . The number operated shows great variations, largely occasioned by the fruit crops upon which so many of the small stills depend. In $188 \%$ it waz 48,415 , while in the next year it rose to 65,652 , only to sink

1. Statist Jahrb. fuer das Ght. Baden and Monatshefte zur Statistik, Etc. 
to 49,180 in 1889 . In 1893 it was up to $\% 1, \delta 13$ and since that year has not been below $60,000 .^{1}$

\section{c. Distribution.}

The distribution of the distilleries in 1899 was as follows: 79,835 or 90 per cent. were in the four South German'States, Bavaria, Wurtemburg, Baden and Alsace-Lorraine; and $53,66 \%$ or 88 per cent. of those operated were found in them. Of the individual States, Alsace-Lorraine contained 31,463, 35.5 per cent. of the entire number; Baden 26,181, 29.5 pc: cent.; Wurtemberg 1\%,166, 13.7 per cent.; Bavaria 10,025, 13.3 per cent; Prussia $\%, 40 \%, 8.3$ per cent., and all the remaining States 1.7 per cent. ${ }^{2}$

When, however, we consider distilling as an independent industry, and exclude those stills run only a few days or weeks the States rank differently. On June 14, 1895, there were in operation 10,950 stills of which $8,65 \%$ were run as an independent business and 2,293 as a subordinate business. According to this classification-entire number operated, number distilling as chief business, number as subordinate business-the data for the chief States was as follows: Prussia, $7,476,6,316,1,160$; Bavaria, 780, 614, 166; Saxony, 879, \% 6 , 103; Baden, 311, 135, 1\%6; Wurtemberg, 534, 108, t26; Hesse, 238, 179, 59 ; Alsace-Lorraine, 212, 78, 134; Hamburg, 82, 76, 6. ${ }^{3}$ According to this, Prussia contained 68 per cent. of all the industrial stills. Saxony followed with 8 per cent. and Bavaria with $\%$ per cent. These percentages show that the real center of the distilling industry is in North Germany and Prussia, and not in the South. Of course it must be remembered that June finds many stills, particularly the agricultural, not in operation.

As to the iocation of the distilleries, whether in the cities or in the country, the present imperial statistics give no information. However, from the classification "industrial" and "agricultural" we can gain an approximate idea of their loca-

1. From Vierteljahrshefte zur Statistik des deut. Reiches, for different years, art. "Branntwein."

2. From V.j. h. zur Statistik, etc., vol. 9, 1900, pl. 2, p. 137.

3. From "Gewerbestatistik der Bundesstaaten," Neue Folge, vol. 114. 
tion. In 1899 there were 1,226 classified as "industrial" and 59,600 as "inclustrial" and "material," viz., those using fruit, wine, pomace, brewers' grains, etc. These two sums may be. taken as fairly representing the numbers in the city and in the country.

In $1895^{1}$ there were $1,16 \%$ distilleries in the twenty-eight cities of over 100,000 population. Berlin is the center of the trade in spirits and has 213 stills. Breslau is also very important as a distillery city. Cologne, Hamburg, Stettin, Bremen and Danzig are the seats of many distilleries with a flourishing export trade. In the South, Munich and Nueremberg are most important.

d. Character.

Distilling in Germany has not developed to such an extent as brewing into a great, independent industry, but has remained more nearly than the latter closely connected with and largely carried on as an auxilliary activity of agriculture.

Two kinds of beer are brewed, the top-fermented or "Weiss" beer, in which the yeast works from above downward, and the bottom-fermented or "lager" beer in which the contrary is true. The brewing of top-fermented beer is a comparatively simple process, and formerly it was common, particularly in Northern Germany, for farmers to own small breweries in which they used considerable quantities of self-raised barle; and hops, selling the product to inn-keepers or owning inns in which the beer was retailed, while the brewers' grains were fed on the place. But the introduction of beer of the Bavarian or lager type since $\mathbf{1 8 3 5}$, and the change in the taste of the people, which now demands the improved beverage, has almost entirely driven brewing from the country. The manufacturs of lager beer is a complex process, demanding an extensive outlay of capital for the plant, and technical skill of a high order for the production of beer that is able to compete with that brewed by the great city plants. So brewing has almost ceased to be a side activity of agriculture, and remains im-

1. Vol. 116 Stat. des Deut. Reiches, "Gewerbe Statistik der Grossen Staedte.' 
portant only as furnishing a very extensive market for the products of the soil.

Distilling, on the other hand, answers all the requirements of an excellent business to be carried on in connection with agriculture. A large investment of capital is not necessary, as a small, simple still can produce as good raw alcohol as the larger, better equipped establishments, though the latter extract a higher per cent. of spirits from the same quantity of mash and at a less cost. Then it is claimed that ther make possible the utilization of materials whose transportation to the markets would not pay on account of low prices, i. e., potatoes, etc. The by-products of the still (schlempe) enable the farmers to keep more cattle than otherwise, through which there is an increased production of meat and manure, the latter making possible a more rational agriculture.

It is true that transportation is not as difficult a problem as formerly, but it is still of inportance, particularly in the eastern provinces of Prussia, where the roads are very poor. In Germany one of the greatest difficulties the farmer has to meet is the supply of food for the cattle. With intensive agriculture, made necessary by the high price of land and dense population, the meadows and swamps are more and more brought under cultivation. This causes a rise in the price of hay and scarcity of pasture, and no fodder crop such as Indian corn is grown. Distilleries furnish a very cheap and excellent food in their residues, as most of the nourishing elements remain after the fermentation. Consequently, if the alcohol produced pays for the materials used, the entire value of the "schlempe" for feeding is gained. "Schlempe" has the quality of increasing the flow of milk and in addition a great quantity of manure, which is so scarce and so valuable, is produced. The more rational agriculture increases the fertility of the land and so the ground rent. In addition it is more easily possible for the farmers to employ the laborers during the winter months, which for the latter is of greatest importance in agricultural districts.

For these and other reasons a large number of enterprising farmers maintain distilleries in connection with their busi- 
ness. The exact number of such plants it is difficult to ascertain. In the census of $1895,5,922$ are reported.

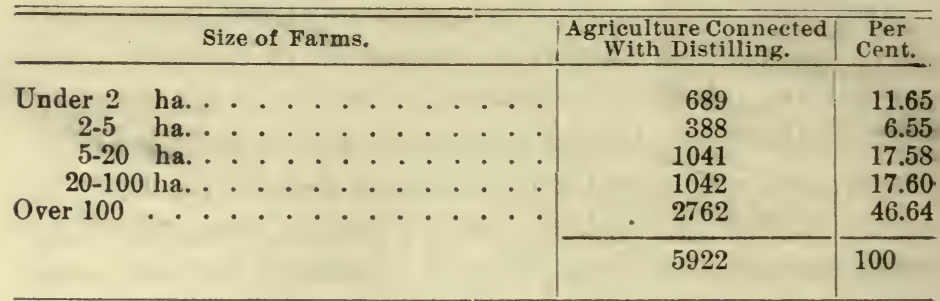

The percentages show that they are usually found on the middle and large-sized farms, as would be expected. But the number is evidently much too small, as the census was taken in the middle of summer when the country stills are not in operation. According to the revenue law those agricultural stills in operation not more than eight and one-half months, between September 16th and June 15th, are only taxed from six to nine-tenths of the regular rate, while those operated duiring the summer pay an extra tax of from 1 to 3 marks a hectoliter. The lower rate is granted by the government for the encouragement of agricultural distilling.

The following data ${ }^{1}$ give a better idea of the real number of country stills. During the fiscal year ending October 1, 1901, there were in operation 74,840 distilleries. Of these 11,960 were classified as "agricultural," 1,211 as "industrial," while the remainder, 61,669 , used materials "not mealy" in character, such as fruit, pomace, wine, brewers' grains, etc. The by-products of these stills cannot be fed to animals as a rule, but they are usually connected with agricultural operations. By "agricultural" distilleries are meant those in operation only during the period indicated by the revenue law in which "the owner distills grain or potatoes raised by himself exclusively, feeds the 'schlempe' to animals owned on the farm, and uses the manure to fertilize the land." The gorernment is very strict in this classification. "Industrial" distilleries are those run as an independent business, with the idea of

1. Vierteljahrsschrift zur Statistik, etc., for the different years, art. "Branntwein." 
direct profit from the spirits produced. Those taxed as agricultural were 16 per cent. of the entire number operated in 1901, and excluding the fruit stills 90 per cent. of all, which last per cent. indicates the great importance of this branch of the industry. Since 1887 there has been an increase in their number of $1,2 \% 3$, but entirely among those using grain, while. the potato stills declined slightly. The latter numbered 6,256 in 188\%-88 and 5,796 in 1900-1, while the former were 4,431 and 6,164 respectively. Industrial distilleries have also been increasing, chiefly among those using potatoes, or from 12 to 61. Grain stills declined slightly from 953 to 884 . However, 1900-01 was an exceptional year, the number having been over 1,000 for the fire preceding seasons. Those establishments using other materials remained fairly constant in number.

A consideration of the distilleries according to the amount and character of the alcohol produced is interesting. In $1899^{1}$ there were 60,926 distilleries operated of which 45,913 or 75 per cent. produced not more than one-half a hectoliter of pure alcohol; 10,395 more produced between 5 and 100 hectöliters, or 88.5 per cent. of all did not yicld over 100 hectoliters, showing how small the great majority are. Of the remainder 1,996 are in the class between 100 and 500 hectoliters, 1,298 between 500 and 1,000 hectoliters, 1,302 between 1,000 and 5,000 hectoliters, and 22 above 5,000 hectoliters. Of the smallest class 41,014 used fruit, wine, etc. Among agricultural stills the average product is much greater, particularly in those using potatoes. In 1899 there were 13,367 of the agricultural plants; $4,7 \% 6$ of them were in the one-half hectoliter class, of which 4,395 used grain and 381 potatoes. The grain stills of the agricultural type are mostly small, only 493 exceeding 100 hectoliters.' On the other hand, 3,764 of the 5,530 agricultural potato stills excesd 100 hectoliters and 1,183 exceed 1,000 hectoliters of product. The existence of so many small grain stills has been explained before as being possible through the direct retail of the product at high prices

1. V. j. s. zur. Statistik etc., 1900 ; vol. 2, p. 154. 
while the potato spirits must be refined before it is fit to be drunk. Among industrial distilleries are found two classes, the very small ones and the largest plants in Germany producing up to 21,000 hectoliters, and representing the highest industrial development in the manufacture of alcohol. The number of industrial stills of all kinds in 1899 was 1,226 , of which 41 used potatoes, 1,064 grain, 29 molasses and 192 other materials. 35 of the potato stills produced amounts not abore 100 hectoliters and 2 alone exceeded 1,000 hectoliters. 317 of those using grain did not exceed 100 hectoliters. Of the remainder 14 exceeded 5.000 hectoliters and 56 were between 1,000 and 5,000 hectoliters. None of the molassez (rum) distilleries were under 100 hectoliters, while 7 ('xceeded 5,000. None of the by-product stills have large capacities, 1 using brewers' grains reaching 2,000 hectoliters, but only 13 of the entire number exceeding 100 hectoliters. Prussia contains most of the large distilleries or 38 per cent. of all producing over 500 hectoliters.

The apparatus used in the majority of the stills is of the simplest kind, only 6.5 per cent. being able to finish the process of distillation in one operation in 1899. Prussia is much better equipped than any other State. and contains " 89 per cent. of all the continuous apparatus. Those in South Germany are mostly very primitive. ${ }^{1}$

As might be inferred from the size of the distilleries, the business organization is, with few exceptions, private in character, and the number of corporations and stock company distilleries is very small when compared with the brewing industry, which had $425^{2}$ stock companies with a capital invested of over one billion marks in 1899. In 1898 there were only 25 distilleries organized as stock companies with a paid up capital of 35 million marks.

The idea of co-operation, largely borrowed from England, has spread rapidly in Germany in recent years and co-operative societies of rarious kinds, many aided by the gorernment,

1. V.j.s. zur. Statistik, 1900 ; vol. 2, p. 134.

2. Richard Wolf, Jahrbuch fuer die Deutschen Actien-Brauereien, 1900. 
have been organized. These are chiefly found among the poorer middle classes and particularly among the farmers. ${ }^{1}$ There were in Prussia in 1898 8,310 ${ }^{2}$ such societies. Of them 5,292 were credit associations for loaning money to the farmers at lower rates than the banks; $1,5 \% 0$ were "productive" societies for co-operation in the production of some commorlity, such as creameries, wine presses, breweries, distilleries, bakeries, etc., and finally 591 so-called "KóonsunVereine," or co-operative stores, meat markets, etc. In addition there are numerous "Terkaufsgenossensehaften," or eo-operative societies among farmers to secure better prices for their produce, storehouses, elevators, etc., being frequently built.

The low price for raw spirits, and the difficulty of maintaining an existence when hampered by inefficient distilling apparatus, has led, within recent years, to the formation of numcrous co-operative societies among the smaller farmers for carrying on distilling and for disposing of the product. The land-owner had to use his fallow crop, the potato, and needed the "schlempe" for fodder, but in many cases with primitive stills distilling could not be carried on except at an absolute loss. Consequently societies have been formed, money has been borrowed from the government at a low rate, and this, together with what the members have contributed, has enabled them to establish neighborhood stills with modern apparatus and economic production. There are no imperial statistics of the co-operative societies and the data is very scanty. In 1895-96 there were reported to be 39 such distilleries. By $1897-98$ the number had risen to 114 and in 1898-99 it was 128. The majority are in Prussia, which contained 54 on June $30,1898 .^{3}$

\section{e. Labor.}

According to the statistics of manufacture there were on

1. For cooperation in Germany see "Das landwirtschaftliche Gennoss Enschaftwesen in Deutschland," Ertel u. Licht. Vienna, 1899.

2. From a catalogue of Prussian co-operative societies existing June 30, 1898, issued by the Central Co-operative Bank, in Berlin.

3. Vierteljahrshefte zur Statistik, etc., 1897, ii., p. 117 ; '98, ii., p. 57 ; '99, ii., p. $144 ; 1900$, ii., p. 114. 
June 14, 1895, 35.458 persons actirely employed in distilleries. This, of course, represents only those connected with the larger industrial establishments. We have mentioned before the great importance of distilleries to the country population, as giving employment during the winter months when work is so difficult to secure. The numbers thus engaged for several months of the year cannot be ascertained for they are classed in the census as laborers, but it must be large in order to run the 13,000 agrieultural stills. We will not consider the thousands who run the brandy stills for a few days or weeks, as they are really fruit gardeners and vine growers. 'The wages as a rule are very low, few receiving over four marks or one dollar a day, which is taken as the standard and paid by the trade-insurance society in case of injury, though the majority receive much less. In addition to the poor pay the conditions of labor are not good. The hours are very long, many distilleries running night and day during the season. The shortest day is twelve hours under these circumstances, and in many plants, which are run short-handed for the sake of economy, the hours are much longer.

Through the courtesy of the director in Berlin we were allowed to examine the books of the Brennerei-Berufs-genossensehaft (distillers' trade insurance society), and thus were enabled to learn the wages paid the men in different parts of the empire in 1900. The following facts are typical of numerous other establishments. In an agrieultural distillery in the province of Posen the conmon laborers received from 1 to 1.50 marks daily, and the chief distillers alone over four marks. In a stoek company distillery in Brunswiek the eommon laborers received under 4 marks, and the ehief distiller 1,500 marks annually. In Nordhausen, the great distillery city of the Hartz, the representative firm of Frieủerick Degen, Successor paid their common labor all under 4 marks, and only 3 skilied workmen over 4 marks. In Gruenwinckle, Baden, a large establishment, the Gesellschaft fuer Spiritus and Presshefe, paid all their common laborers, 141 in number, under 4 , marks, boys 1.80 marks, and a few skilled laborers orer 1 
marks. In Hamburg, the firm of Peters paid 72 under 4 marks, 8 skilled men over 4 marks, and 7 boys 3 marks.

The wages are lowest in West Prussia and Posen, where the common distillery laborer, in many cases, does not receive more than 1 mark and from that to 1.30 marks, or from twenty-five to thirty-seven and a half cents a day. These conditions exist, though there is a great scarcity of labor. The men of the provinces go in great numbers to the West, where they work in the mines and factories at much better wages, and Poles and Bohemians come in to take their places who are satisfied with the miserable amount paid. The best wages for common labor are paid in Saxony and in the manufacturing districts along the Rhine.

f. Materials Used.

1. Potatoes.

Of all the materials used in distilling in Germany potatoes are the most important, 81.5 per cent. of all the alcohol produced being made from them. In describing the development of the industry in Prussia in the early part of the century, we mentioned the introduction of the potato as a root crop for the fallows, particularly in the sandy portions of Northern Germany. Other fallow crops such as turnips, beets, etc., have been introduced, but the potato has always remained the principal one. In 1898, 10.8 per cent. of the arable land of the empire was planted to potatoes; rye and oats alone having a greater acreage. Of the crop harvested about 9 or 10 per cent. is annually distilled into alcohol. The average for the last ten years is 9.25 per cent., while that for 1898 is 9.5 and for $1899,10.5$ per cent. We have placed together the acreage, the amount harvested and the amount distilled in the various districts in 1899 , in order to ascertain the proportion distilled in different sections of the country. The per cent. of the crop distilled in East Prussia was 15.5; West Prussia, 1\%.2 ; Brandenburg, 18.3; Pomerania, 21.5; Posen, 21.3; Silesia, 14.5 ; Saxony, 6.1; Schleswig-Holstein, .5: Hanover, .4; Westphalia, .0; Hesse-Nassau, 1.1; Rhine Province, .1; Holhenzollern, .1; Kingdom of Prussia, 12.8; 
Bararia, 3.6 ; Saxony, 9.9 ; Wrurtemberg, .6; Baden, .. ; Hesse, 2.7; Mecklenburg, 5.8; Thuringia, .8; Brunswick, 2.8; Anhalt, 12.8; Alsace-Lorraine, . 2 ; Germany, 10.5.

The seat of potato culture is in the Eastern prorinces of Prussia, and here the amount distilled is very large, being nearly one-fourth of the quantity available. It would be difficult to orerestimate the importance of the potato and the alcohol industry to the farmers of these districts.

The quantity of potatoes made into alcohol annually varies greatly with the crops, but on the whole there has been a decrease in the last twenty years, except for the last few years, from the amounts used before $188 \%$. The estimates in 1,000 tons for a number of years follow, a ton being 1,000 kilograms: ${ }^{1} \quad 1887-88,2,009 ; 1888-89,1,699 ; 1889-90,2,083$;

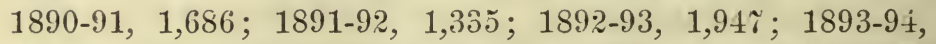
2,148 ; 1894-95, 1,804; 1895-96, 2,210; 1896-9\%, 2,116; $1897-98,2,261 ; 1898-99,2,586$.

\section{Grain.}

Next in importance among the materials used is grain, chiefly rye, though within recent years a considerable quantity of incian corn alcohol has been produced. Some malted barley is necessary in preparing the mash and small quantities of buckwheat are also distilled.

Rye is the principal breadstuff of Germany, relatively little pure wheat bread being made. As such it stands first in acreage among the agricultural crops, 5,495,191 hectares or 21 per cent. of all the land under cultivation being planted to this grain in 1899. The arerage crop is between seren and one-half and eight and one-half million tons. Of this over 80 per cent. is grown in Prussia, the provinces of Posen, Silesia, Brandenburg and Hanover producing the largest amounts. In South Germany, Bararia produces from seven to eight hundred thousand tons, or as much as Posen.

The amount distilled is relatively small. Before 1895 the various kinds of grain were grouped together in the statistical tables. The following data, however, gires a fairly good idea

1. From Monatshefte, and V. j. s. zur St atistik, etc., for various years. 
of the rye used,as only a relatively small amount of barley and other grains were distilled. The estimates are in thousanci tons: $1887-88,205 ; 1588-89,329 ; 1889-90,332 ; 1890-91$, $350 ; 1891-92,491 ; .1892-93,323 ; 1893-94,325 ; 1894-95$, $322 ; 1895-96,293 ; 1896-97,265 ; 1897-98,270 ; 1898-99$, 282. ${ }^{x}$ Taking 280,000 tons as the quantity used by the distillers in 1899 , we find that it was 4 per cent. of the amount remaining in the country for consumption after deducting exports and seed and adding imports.

The distillation of indian corn has been inereasing very rapidly in recent years. The amount so used has been separately reported for four years only, but in that time the quantity has nearly doubled. In 1895-96 there were used 36,797 tons; 1896-97, 46,871; 1897-98, 59,765; 1898-99, 59,801. The corn used is entirely imported, chiefly from America and Russia. Germany is a growing market for this product.

There were also used in 18993,621 tons of "other mealy materials," representing chiefly potato starch and the wastes of stareh manufacture.

\section{Molasses.}

The distillation of rum from molasses is at present of little importance. In the early years of the beet sugar industry the last product of sugar-making, molasses, was placed upon the market at low prices and large quantities were used for distilling purposes. But.with the advance in the technic of sugar manufacture methods of more perfectly crystalizing the sugar were discovered. Consequently, the price of good molasses raised greatly, and that from which the sugar had largely been extracted was an unsatisfactory raw material for distilling. In addition, alcohol from molasses is usually from one to one and one-half marks lower in price than potato or grain spirits. These conditions have greatly depressed this once flourishing branch of distilling.

In 1895 a further hindrance was placed in its way by the restrictions of the graduated distilling tax of that year, according to which the molasses distillers must pay an extra tax

1. Sources same as for potatoes. 
of 15 marks a hectoliter for all the spirits produced above twenty per cent. more than the tax-free quantity-the socalled "Kontingent"-allotted them by the law of $188 \%$. This sets a limit on production which cannot be exceeded, even under the most favorable circumstances, and though the pricc of molasses has been very low of recent years the rum produced has not increased in amount.

The distillers using molasses are chiefly located in the beet sugar districts of Northern Germany, the province of Saxony, Anhalt, Hanover, Brunswick and Silesia. The city of Madgeburg is the center of the sugar industry as well as of molasses distilling. The number of tons of molasses and beets used in recent years follow: 188\%-88, 27,720; 1888-89, 25,487 ; 1889-90, 28,039; 1890-91, 73,5 $41 ; 1891-92,95,3 \% 0$; $1892-93,37,461 ; 1893-94,33,826$; 1894-95, 76,459; 1895-96, 43,$006 ; 1896-97,44,540 ; 1897-98,46,970 ; 1898-99,34,986$.

4. Other Materials.

The other materials used are chiefly brewers' grains, fruit, wine, pomace, etc. The amount of brewers' grains has declined greatly in recent years, being better utilized as cattle food when spirits are low in price. 'The following statistics are in thousand hectoliters: 1887-88, 299; 1888-89, 279; 1889-90, 233; 1890-91, 23\% ; 1891-92, 253; 1892-93, 225; $1893-94,188$; 1894-95, 180; 1895-96, 183; 1896-97, 165; 1897-98, 128; 1898-99, 116.

Fruits, wine and pomace depend entirely on the crop, but the production of brandy is considerable as the materials used show: $188 \mathrm{i}-88,414$ thousand hectoliters; $1888-89$, 1,076; 1889-90, 552; 1890-91, 684; 1891-92, 670; 1892-93, 678; $1893-94,1,527$; 1894-95, 1,034; 1895-96, 679; 1896-97, 909; $1897-98,789 ; 1898-99,708$.

g. Product.

In the quantity of alcohol produced Germany stands first among the Nations, Russia probably follows, and then come France, the United States and Great Britain. The following data have been compiled from the statistical publications of

1. See Vierteljahrshefte zur Statistik, etc., 1897, vol. ii, p. 116. 
the nations mentioned. No estimates for Austria are available since 1896, and the amounts of several others have been beyond our reach. The quantity for Russia is somewhat uncertain, but it is official: Germany produced 295.1 million liters of pure alcohol in 1895; 1896, 333.3; 1897, 310.0; 1898, 328.7; 1899, 381.5. Tiussia's amount for 1895 was $353.7 ; 1896,373.1 ; 1897,359.4 ; 1898,344.5$. France in 1895 yielded $216.5 ; 1896,202.2 ; 1897,220.8 ; 1898,241.2$; 1899, 260.0. The United States in 1895 reported 154.9; $1896,170.1 ; 1897,121.6 ; 1898,158.3 ; 1899$, 189.4. Great Britain in $1895,117.1 ; 1896,128.7$; 1897, 142.0; 1898, 158.3. Austria, 1895, 138.8; 1896, 139.\%. Hungary, 1895, $94.2 ; 1896,94.4 ; 189 \%, 102.6 ; 1898,105.4$.

The amounts and kinds of alcohol produced in Germany since the formation of the Union in $\mathbf{1 8 8 7}$ and the introduction of the new system of taxation are contained in the following table. 


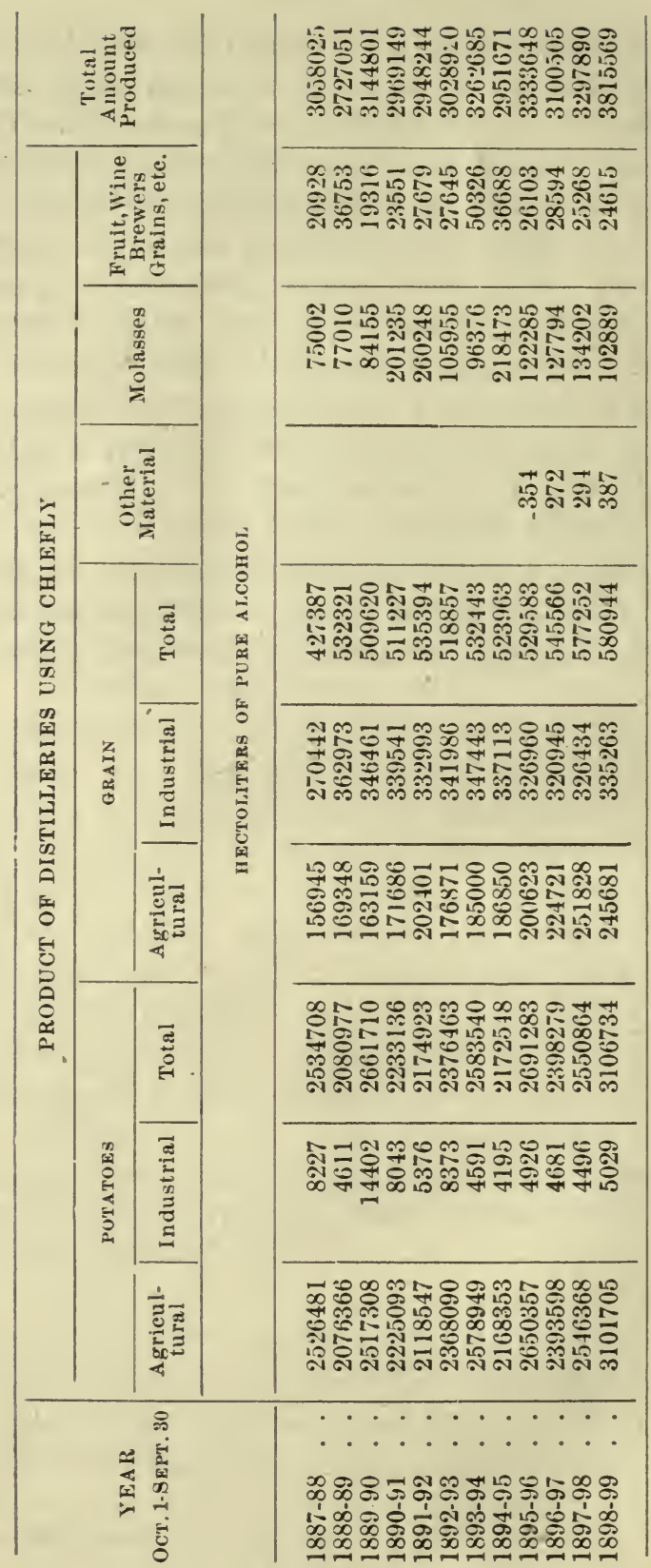


The immediate influence of the higher taxation was to considerably lessen the amount of spirits produced, which in the years before $188 \%$ is estimated to have averaged four million hectoliters for the entire empire. But this was an overproduction, according to the market condition, which had been unfavorable since 1884. In the early eighties the German industry had been greatly favored by the rapid expansion of the export trade, which rid the home market of the excess product, and so aided in the maintenance of good prices. The average yearly export between $18 \% 0$ and ' 79 was 49.1 million liters and between 1880 and ' $84,74.18$ million liters. This export was chiefly to the wine growing countries of Southern Europe, whose vineyards were being ravaged by the Phylloxera at this time. . Especially was export favored by a trade treaty with Spain, which country imported German spirits to take the place of the wine exported to France as a result of the short French crops. However, these favorable conditions did not last long. Cheap Russian potato spirits, favored by an export premium, as well as the Austrian and American product, began to compete with Germany in her best markets. Between 1885 and 1892 the exports declined from 87.7 to 8.3 million liters, and the result was a sharp fall in price from 53.40 marks a hundred liters of pure spirits in 1883 to 34.80 marks in $1888 .{ }^{1}$ In addition, the potato crops were unusually good for several years, and they were distilled in spite of the ever-sinking price of spirits. 'The industry faced a crisis. Efforts were made by the producers to limit the amount distilled, but without success. This was the condition at the passage of the law of $188 \%$, which increased the tax by 300 per cent. In spite of higher taxation there continued to be an excess of several hundred thousand hectoliters over the needs of Germany, which could be only partially exported on account of Russian and Austrian competition, and the remainder greatly depressed the market.

In 1885 the government sought to still further lower the production by imposing an additional tax on all plants pro-

1. H. w. b. der Staatswissenschaften ii, p. 1064, 1095 and Vierteljahrshefte zur Statistik, I900 i, prices. 
ducing more than 300 hectoliters yearly. The amount by which this special tax exceeds the export drawbacks is used as an export premium of 6 marks a hectoliter to free the domestic market of the excess. The immediate result was a great increase in export and a rise in price.

The world's price, however, did not follow that of Germany, for Roumania and Hungary, as a result of the excellent maize crops, could supply spirits more cheaply than Germany, and exports declined again in 188\%. After 1898 they assumed large proportions once more, chiefly because of the Russian alcohol monopoly, which was extended over 35 provinces in 1898. The better prices and good potato crops have led in the last years to a renewed activity, particularly in potato distilling, with an increased production, the amount for 1899 being the greatest since $188 \%$.

From the table giving the product of the distilleries of various classes we are now in a position to ascertain the amount produced by the purely agricultural stills, and thus to gain a still clearer idea of their importance to the German industry. Bringing together the product of the country stills, potato and grain, but not including the fruit, we have the following results for the last five years: The product of the agricultural stills for 1894-95 was 2,355,203 hectoliters, 79.3 per cent. of the total product; 1895-96, 2,852,980 hl., 85.5 per cent.; 1896-9\%, 2,618,319 hl., 84.4 per cent.; 189\%-98, 2,798,196 hl., 85.1 per cent.; 1898-99, 3,347,386 hl., $8 \% .7$ per - cent. The farmers of Germany, according to this, produce from materials raised by themselves over 80 per cent. of all the spirits distilled in the country, and all the residues from this, the chief branch of the industry, after being fed to great herds of cattle, return to the soil. But in addition to the 120 million marks coming to the farmers yearly from the sale of their alcohol, there is also the demand of the industrial distillers, who are among their best customers for potatoes, rye, barley and other products.

An estimate of the money value of the materials taken from agriculture and returned to it by the distillers is inter- 
esting, and may help to an appreciation of the significance of the industry to the farmers of Germany. Taking the average market price for several years as the basis of our estimate, we secure the following results. The distillers used in 1899, 258 million double centners of potatoes at 3 marks a double centner, or an entire value of $7 \% .5$ million marks; 346 million double centners of grain at 15 marks a double centner, or 51.9 million marks. An estimate of the value of the fruit is impossible. Together these amounts give the sum of 129.4 or round 130 million marks as the value of the product taken from agriculture by the distilling industry in 1899. If we also include the materials consumed by the brewers, for the sake of completeness, we have the following: In 1899 round 18 million double centners of brewing barley was used at 18 marks a double centner of a value of 324 million marks; 300,000 double centners of other grain worth 4 million marks; 171,000 double centners of hops at 300 marks a double centner or 51.3 million marks. Together this made a value of 379.3 million marks paid for material by the brewers. Placing the amounts for distilling and brewing together, we have as an estimate of the value of the raw material taken from agriculture in 1899, 408.7 million marks.

But the large amount of by-products given back to agriculture must not be forgotten. As estimated by an expert ${ }^{1}$ they have a yearly value of 62.2 million marks:

From the distillers-

Potato "schlempe," 25 mil. d. c. @ 60 pfennigs..15.0 mil.m. Distillers' grains, 600,000 d. c. @ 9.00 marks.... 5.4 mil. m. From the brewers-

Brewers'-grains, '18 mil. d. c. @ 2.00marks.....36.0 mil.m. Malt sprouts, 720,000 d. c. @, 8.00 marks....... 5.8 mil.m.

62.2 mil. $\mathrm{m}$

Dr. Bode estimated the amount of land needed in 1892 to produce the materials used by the distillers and brewers at $1,658,605$ hectares or 16,586 square kilometers, i. e., a plot of

1. Dr. Th. Remy in E. Struve's Erlass eines Surrogat-Ver bots, etc. Berlin 1899 , p. 50. 
land larger than Baden, 15,0S1 square kilometers or Saxony, $14,92 \%$ square kilometers, and one-fifteenth of the entire agrıcultural land of Germany. ${ }^{1}$

From an economic and sociological standpoint, it is a grave: question whether or not Germany can afford the use of such a per cent. of her land and labor in the production of an article of which the vast majority, at least at present, is used in ways only injurious to the consumer, and lessening his demand for other things which would add to the physical, mental and spiritual capabilities of the nation.

IV. Possible Developments.

a. The Extensive Use of Spirits for Technical Purposes and the Possible Results Therefrom.

We have seen the great importance of the distilling industry to the agriculture of Germany at the present time, but within recent years possibilities of development have opened up that seem almost unlimited. We refer to the extension of the use of alcohol for technical and mechanical purposes.

The German law allows spirits made unfit for human consumption by the addition of spirits of wood, pyrimidin basis, turpentine, sulphuric acid, shellac, etc., to go untaxed. The most common mixture used is the "algemeine denaturirungsmittel," which is composed of four parts of spirits of wood, and one part of pyrimidin basis, and is procurable from the revenue officials at a cost of 75 to 80 marks for 100 liters. Anyone may use this preparation in the proportion of $1 j$ liters of it to 100 liters of pure alcohol. The mixing mus: take place in the presence of two revenue officials, and the alcohol must not be less than 73 per cent. pure. Since March, $189 \%$, the retail of such "denaturirte" spirits is not conditioned, needs no concession or license, and in Prussia the retailers pay no business tax (betriebs-steuer). There are only certain conditions to be complied with, as to the announcement of the business to the tax officials, and as to the strength of the spirits sold. ${ }^{2}$

All. these arrangements have been made by the government

1. Dr. Wm. Bode, Der deut. Alkoholfrage. Leipsic, 1892, p. 10.

2. Kalendar fuer das landwictschaftliche Gewerbe, 1898; p. 5 . 
with the view of furthering the use of such spirits, and the increase in consumption within recent years has been suprising. The amounts used in the former tax union were as follows: 1880-81, 9.32 mil. liters; 1882-83, 13.00 mil. liters; 188t-85, 14.41 mil. liters; $1886-8 \%, 18.31$ mil. liters. ${ }^{1}$

For the years since the law of $\mathbf{1 8 8 7}$ and for the entire empire the development has been as follows: ${ }^{2}$ 188\%-88, 38\% thousand hectoliters; 1888-89, $431 ; 1889-90,531 ; 1890-91$, $519 ; 1891-92,551 ; 1892-93,607 ; 1893-94,664 ; 1894-95$. $719 ; 1895-96,808 ; 1896-97,867 ; 1897-98,889 ; 1898-99$, $990 ; 1899-1900,1,043 ; 1900-01,1,156$.

During the fourteen years there has been an increase in the amount of absolute alcohol so used of 298 per cent., and at the same time the per capita use has increased from .8 liter: in $1837-88$ to 2.0 liters in 1900-01. During the same period the smounts of alcohol prepared with the general "denaturirungs-mittel" were as follows: 1887-88, 138 thousand hectoliters ; 1888-89, 176 ; 1889-90, 245; 1890-91, 244; 1891-92, $275 ; 1892-93,315 ; 1893-94,364 ; 1894-95,414 ; 1895-96$, $479 ; 1896-97,528 ; 1897-98,529 ; 1898-99,610$. In 1899, 442 per cent. more spirits were prepared with the mixture than in 1888 . In 1888,35 per cent; in 1899,61 per cent. of all the "denaturirte" spirits was made with the general mixture. As the spirits thus prepared is that which is used for heating, lighting, motor running, etc., we see that the increased use has been almost entirely along these lines.

With the appearance of the incandescent gas mantel, or Wellswach burner, the possibility of the use of spirits for lighting purposes existed, and inventive genius has succeeded in producing spirit-lamps for general lighting which are in every way excellent, giving a soft but brilliant light. The lamps are clean and easily cared for, as there is no danger of smoke. They produce no heat and are in almost every particular superior to the petroleum lamp. In addition there has been a great deal of interest in recent years in the production of spirit motors, which can successfully compete with the petro-

1. Zeitschrift fuer die Spiritus-industrie. 1897 ; p. 179.

2. Vierteljahrshefte zur Statistik. etc., 1900: ii.. p. 11 F. 
leum and gasoline motors so extensively used by small manufacturing establishments in Germany. Encouraged by prizes offered by the trade and by Emperor William, excellent machines have been invented, and the extensive exhibits of such motors in the German agricultural fairs, etc., in the last three or four years' show that from the standpoint of efficiency, safety and cleanliness they have no need to fear the competition of petroleum and gasoline. Only one thing stands in the way of the almost unlimited extension of the use of spirits for light, heat and power production, and that is the price, which must be low enough to compete with petroleum and its products. The chief difficulty in the past has been the connection between the price of alcohol for drinking and for technical purposes. ' If the two could be divorced, and the price on the former raised very materially, so that the profit on its sale would allow the sále of "denaturirte" spirits at les, than the cost of production, the problem would be solved.

In 1899 an organization of the producers and refiners came into existence, which has the accomplishment of this very thing in view, namely, the alcohol trust or the "Centrale fuer Spiritus-Verwertung." This is a union of the chief dealers in and refiners of spirits, and the "Verwertungs-Verbande Deutcher Spiritus-Fabrikanten" joined together to secure better prices for their product. For many years, as we have seen, the distilling interests had been suffering from low prices. Protected by a high tariff from foreign competition, and rided by the low $\operatorname{tax}$ on a considerable portion of the product, there seemed to be no reason why an organization of the principal producers might not be able to control the maiket and secure higher prices. Many efforts were made toward these ends, but not until 1899 did any of the plans become is reality. Early in the year the scciety of the leading distillers, "Verein der Spiritus-Fabrikanten," began the agitation looking toward union of all the alcohol interests. The intellectual leaders of the movement were successful, and by April 1st, 75 per cent. of the agricultural distillers had been secured. The remainder of the dealers and manufacturers were tooweak to resist and joined the movement, which began its offi- 
cial activity October 1,1899 , controlling about 90 per cent. oi the product.

The plan is as follows: ${ }^{1}$ The great firms have organized the "Centrale," with a capital of $6,000,000$ marks, nominally, but in reality with a financial strength represented by the capital of all the firms belonging to the Union. The "Centrale," with headquarters at Berlin, has pledged itself to buy" all the spirits that distillers supply at a price agreed upon at the beginning of each business year, October 1st; to place the spirits on the market at the highest price which seems wisc, not excessive, but one which will give a fair return on capital; and at the end of the year to pay the various distillers tinc "verwertungs-praemie," or profits per hectoliter, after the cost of handling and sale have been deducted. The producers, on the other hand, have bound themselves to the "Centrale" for nine years and all spirits produced by them must be delivered to the trust for sale irrespective of the market price. Of course the hope is that through union the market can be controlled, and better prices secured for all. Now the part that is of particular importance to us. Liquor for drinking purposes is to be sold at high prices, while the excess, which would lower the price of all if placed on the market, is to be mixed with the "denaturirungs-mittel," and sold for technical purposes. The "Centrale" has every interest in furthering the "use of "denaturirte" spirits as much as possible, as only by the extension of such use can it hope to be successful in it; plans, and its efforts are meeting with great success everywhere.

The use of spirits for lighting had not been greater before because the dealers would not give up the habit of large profits which hindered the expansion of the trade. Only in certain districts, especially in Saxony, were the prices low, and the dealers rejoiced in a large and steady trade. The "Centrale" considered these conditions and decided on the following plan, adopted in June, 1900. The trust fixes the retail price for different localities and sells to the dealers at prices differing

1. The statements concerning the trust and its activities are largely based on an interview with Prof. Wittleshoefer, the director of the Centrate, who kindly explain1d the organization and its plan. 
from two to three marks a hectoliter. Those binding themselves to the established retail price, which allows 20 per cent. profit, receive the spirits from the "Centrale" at the lower price. The trust advertises the sale in the papers and the stores where spirits can be secured, thus forcing the others to sell at the lower price. The merchants took kindly to the plan and in October, 1900, four months after its introduction, there were 25,000 pledged to sell "Centrale" spirits at a un1form price. Stores are being opened in many localities dealing only in spirits and all sorts of lamps, stores, etc., for its use. From June to December, 1900, over 11,000 such stores were sold, and many more lamps. The management of the royal railway of Saxony introduced spirit-lamps into a large number of their stations where gas and petroleum were formerly used and have contracted with the trust for their spirits at a reduced price. The Prussian railway management has also been experimenting, and has ordered spirit-lighting for all the workmen's rooms where oil has been used. The Bavarian railways have also introduced spirit-lamps quite extensively. In 1900, the Prussian railway system used 600,000 liters of "Centrale" spirits; the Bavarian 189,000, and the Saxon 50,000. Cities are also introducing spirit-lamps for street lighting, and by December, 1900, twenty-five had contracted with the "Centrale" to supply spirits to them till 1908.

In order to further the use of spirit-motors the trust has established a special price on spirits for power production that makes it able to compete with gasoline, when quantities not under 5,000 kilograms are purchased.

The significance of this increased use of alcohol for heating and lighting to the distillers and particularly to the farmers of Germany must at once be apparent. It opens up to them an almost unlimited demand for the product of their stills. If alcohol can be placed on the market at the present prices, from five to seven and one-half cents a liter, there is no reason why it should not take the place of a great part of the petroleum that is now used. Germany is absolutely dependent on foreign countries for coal oil and imports great quantities of it, chiefly from America. If, by the general introduction of 
spirits for heat and light, the nation ean partially free herself from her dependence on the Standard Oil Company, it would be the cause for great rejoicing.

But at the same time the country would be working a blessing to her agriculture difficult to overestimate. With a profilable market for spirits, a great many farmers, who do not now own plants, would undoubtedly earry on distilling in connection with their other operations, thereby greatly benefiting the soil, and general agricultural interests. In addıtion, there are thousands of square miles of sandy ground in Northern Germany which denuded of their forests are dreary wastes, or are being reclaimed at great expense by the government, that are well suited to potato culture, and could easily be brought under cultivation if planted to them.

Distilling in Germany is certainly of greater importance, particularly to agriculture, than is generally supposed, and development along the lines indicated will everywhere be observed with interest.

A Bibliography of the prineipal works used, but not including the statistical publications of the government:

Baer, A., Alcoholismus, Leipsic.

Bode, Dr. W., Der deut. Alkoholfrage, Leipsic.

Conrad, J , Hwb. der Staatswissenschaften, Leipsic ; article "Branntwein." Dieterici, Stat. Uebersicht der wichtigstcn Gegenstaende, etc., in preuss. staates, Berlin, 1839-45.

Engle, E, Der Branntweinbrennerei in ihrer Beziehung zur Landwirtschaft.

Ertel, u. Licht, Das lws. Genossenschaftswesen in Dl., Vienna.

Ferber, C. W., Beitraege zur Kentniss, etc., der Preuss. Monarchie, Berlin, 1829.

Glaeser, Die Steuersysteme bei der Branntweinfabrikation, Brieg.

Grotjohn, Alkoholismus.

Laves, " Die"Eutwickelung der Brennerei, u. der Branntweinbesteuerung in Dl." in Jhb. fuer Gesetzgebung, vol. ii, 1887.

Meitzen, Aug., Der Boden u. die lws. Verhaeltnisse des Pr. Staates, Berlin.

Meyer, S, Die interationale Spiritus-Produktion, Vjs. fuer Volkswirt-schaft; 1883.

Stahlschmidt, C., Die Gaehrungs Chemie, Berlin.

Struve, E., Bayerisches Brau-Gewerbe, Leipsic.

Wolt, Die Branntweinstever.

Zeitschrift fuer die Spiritus-Industrie, Berlin.

Alcohol, a periodical, Berlin. 
THIS BOOK IS DUE ON THE LAST DATE STAMPED BELOW

AN INITIAL FINE OF 25 CENTS WILL BE ASSESSED FOR FAILURE TO RETURN THIS BOOK ON THE DATE DUE. THE PENALTY WILL INCREASE TO 50 CENTS ON THE FOURTH DAY AND TO \$1.00 ON THE SEVENTH DAY OVERDUE.

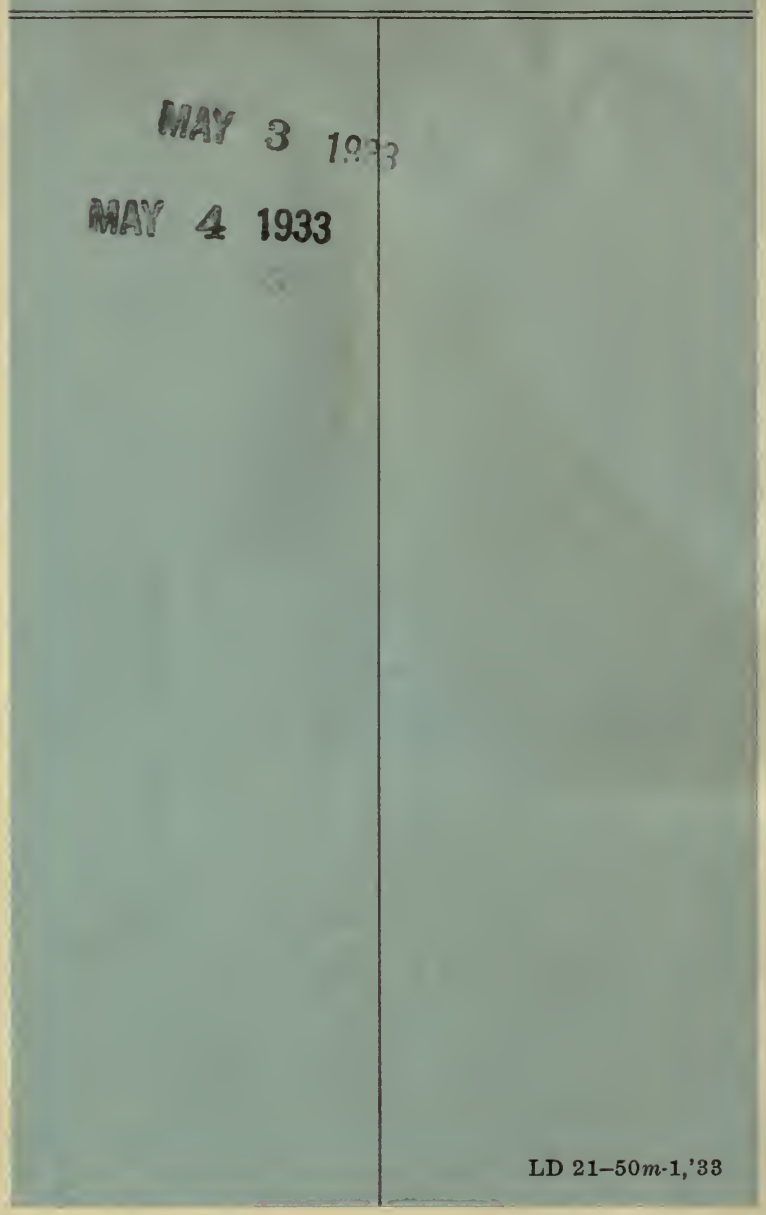




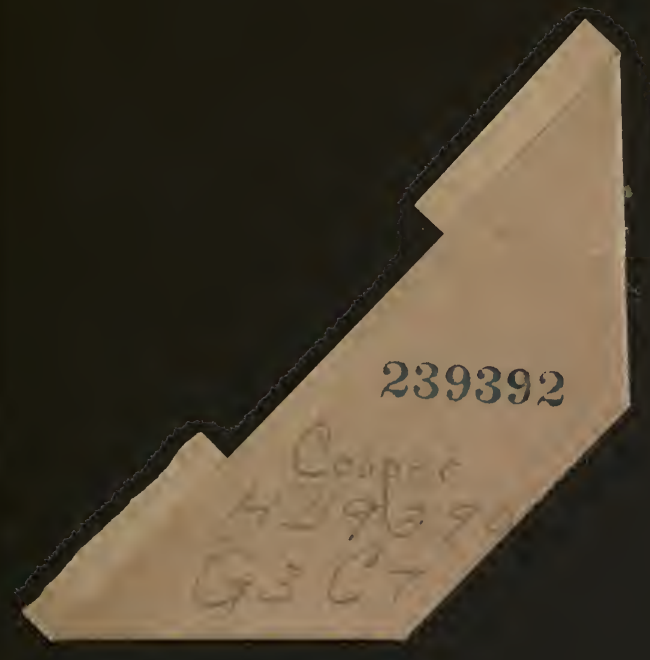




\section{$\frac{15}{4}+\frac{1}{4}$}

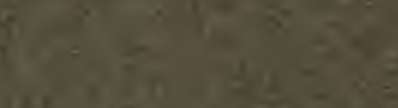

\section{T.}

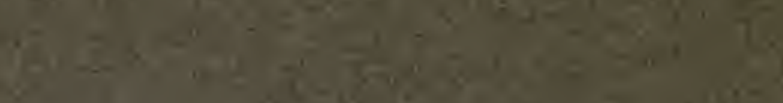

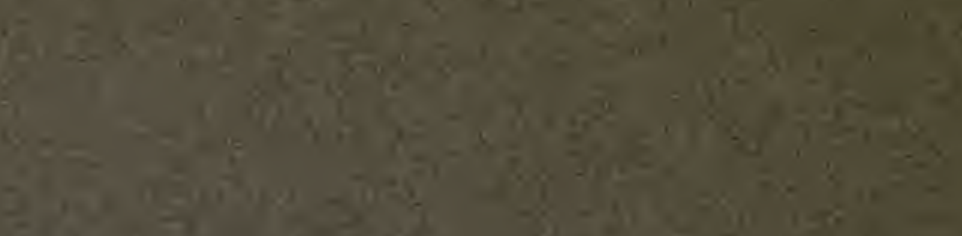

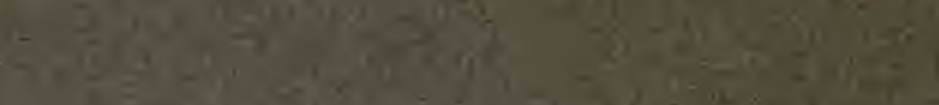

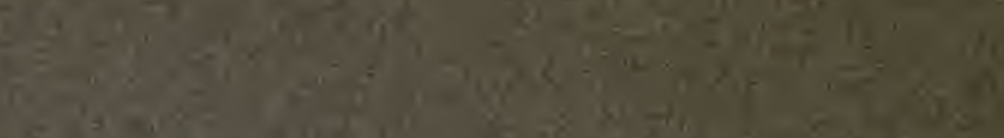

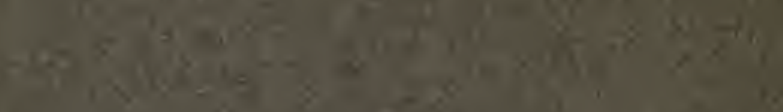

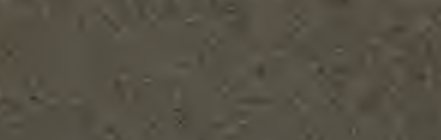

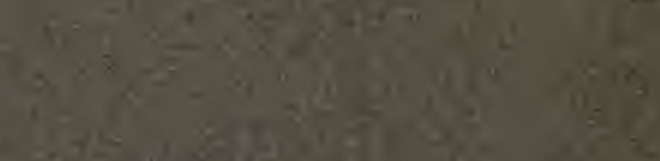

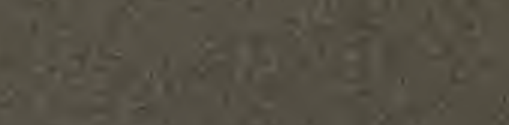

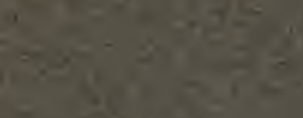

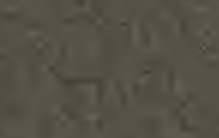

$\cos ^{2}+2$

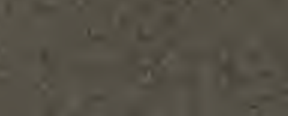

$=17$

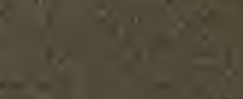

78

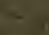

(1)

$i^{1}$

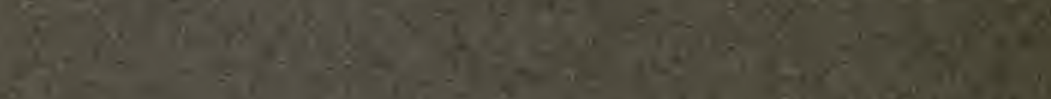

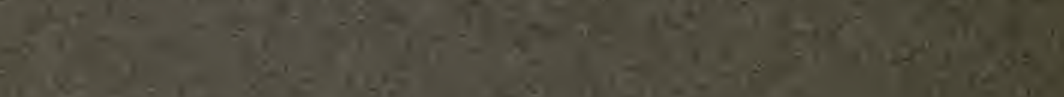

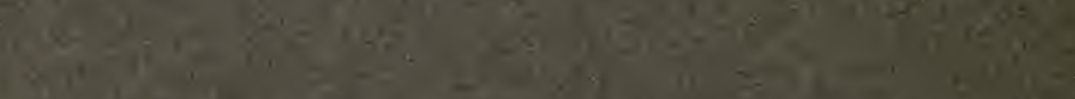

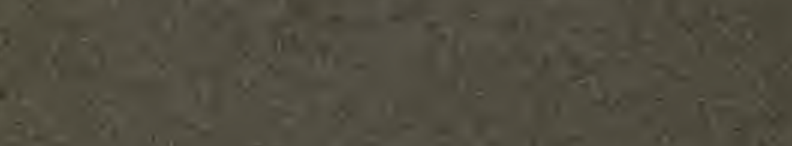

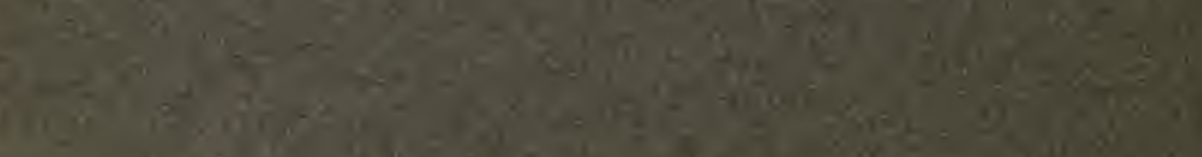

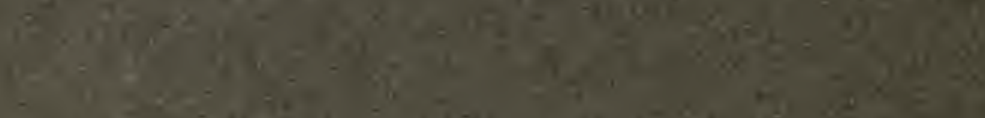

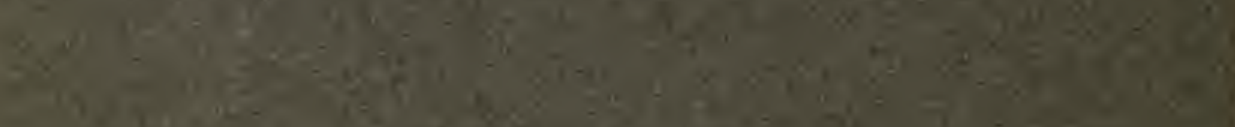

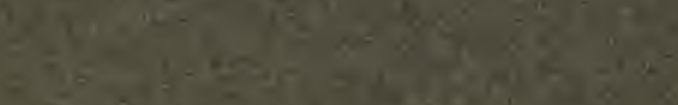

